DOI: $10.14451 / 1.198 .7$

\title{
ПРОБЛЕМЫ ВЫБОРА СИСТЕМЫ КРИТЕРИЕВ ФОРМИРОВАНИЯ ИНСТИТУЦИОНАЛЬНОЙ СРЕДЫ
}

\author{
(C) 2021 Наумов Александр Сергеевич \\ кандидат экономических наук, старший научный сотрудник \\ Институт экономики РАН, Россия, Москва \\ E-mail: as.naumov@mail.ru
}

Изложены предложения по системе критериев, позволяющих осуществлять выбор приоритетов национальной институциональной среды и инновационной политики.

Ключевые слова: институциональная среда, инновации, информационные потоки, государство, наука, постиндустриальное развитие, критерии, синтез, экономическое и социальное развитие.

Перед современной Россией как никогда остро стоит вопрос выбора пути. Предлагаются различные теории от постиндустриального развития до перехода к собственному. Что выбрать? Для начала следует обратиться к прошлому. Выдающийся мыслитель Давид Юм писал: «Все планы государств, которые предполагают осуществление огромных преобразований в нравах людей, основаны только на воображении» [1], проще говоря - на утопии. Так, в России либеральные преобразования насаждались весьма своеобразно. Эффект не мог быть достигнут, общеизвестно, что либерализм на Западе явился следствием развития капиталистических отношений, а не причиной, как это произошло в России начала 19 века, да и по сей день. Жак Руссо, который развил учение о естественной свободе в трактате «Об общественном договоpe» (1762 г. к национальному согласию, национальной воле и национальному единству) писал о том, что « Для создания нового, совершенного общества необходимо достигнуть обнаружения и действия именно общей воли... естественное право, как бы мы его не определяли, очевидно, не может допустить, чтобы дитя властвовало над старцем, чтобы глупец руководил мудрецом, и горсть людей утопала в роскоши, тогда как огромное большинство нуждается в самом необходимом» [2]. Вот в чем вопрос. Отчасти, ответ можно получить у Л.Никифорова в монографии «Тенденции общественного развития и трансформация российского общества» - «Разрыв между выбираемыми ориентирами развития и его объективными направлениями в мире не позволяет стране реализовать ее собственные специфические черты, предопределяющие богатство российского ресурсного, пространствен- ного, человеческого, цивилизационного потенциала, рационально использовать имеющееся общественное богатство» [3 - С. 73].

Думается, что в деле выбора ориентиров и устранения противоречий в путях развития экономики может помочь научное знание и информация, которые обладают огромной общественной ценностью. В 21 веке, с ростом естественного развития общества и НТП, информация уже становится стратегическим ресурсом. Емкость информационно-теоретических потоков, циркулирующих в современной науке, огромна, однако, как писал Карл Маркс в статье «К критике гегелевской философии права» (1844): «... теория становится материальной силой, как только она овладевает массами. Теория способна овладеть массами, когда она доказывает ad hominem (Argumentum ad hominem - доказательство применительно к данному лицу - АСН), а доказывает она ad hominem, когда становится радикальной. Быть радикальным - значит понять вещь в ее корне (radix в переводе с латинского «корень - АСН). Но корнем является для человека сам человек... » [4 - с.442]. Это доказывает, что для выбора системы критериев необходимо перенаправить информационные потоки, содержащие в себе полезную составляющую, на раскрытие основных черт и специфику современного развития общества и, прежде всего, на людей их вовлечение в изменения среды обитания. Л.Никифоров писал по этому поводу следующее: «изменение содержания и структуры видов и форм отношений собственности, размывание социально-классовых основ структуры общества... приводит к « возникновению новых аспектов общественной интеграции» [5. С.16]. Аспекты новые а мышление старое. Что мы и на- 
блюдаем в настоящее время. Изменения, разрывы, размывания. Как с этим справиться? Необходимы новые институты развития. Современные технологии Интернет, бурно развивающегося сегодня в России, могут помочь в этом деле, так как позволяют технически объединить и классифицировать научное знание, содержащееся в информационных потоках, создать единую базу данных, разработать и внедрить интернетресурс, способный объединить существующие и способствующие повышению культуры информационного восприятия, а это чрезвычайно важно, как в деле ускорения научно-технического и социального прогресса, так и в восприимчивости населения страны прогрессивными идеями с последующей их «материализацией» - «Зри в корень», как выразился Козьма Прутков (Выражение «зри в корень» означает: сумей найти самую суть, из которой произрастает проблема.

Так, российский исследователь Г. Малинецкий в своем выступлении совершенно справедливо задается вопросами: «Почему на смену капитализму сейчас приходит Новое Средневековье. Что предлагают миру Шваб и компания и почему это не поможет. Почему людям всё меньше и меньше находится места в новом мире и как тотальное вынужденное безделье рушит саму общественную ткань. Есть ли здоровый выход из этого?» [6]. Автор дает некоторые рекомендации, к которым, на мой взгляд, стоит прислушаться, тем, кто управляет современной российской экономикой.

В настоящий момент развития государств, по мнению ряда исследователей, «приоритет отдается уникальным разработкам, прокладывающим путь техническим нововведениям в таких областях, как информатика, микроэлектроника, биотехнология, генная инженерия, аэрокосмический комплекс. Как ожидается, именно на этих направлениях результаты исследований откроют дорогу бурному развитию новых отраслей и производств» [7-79 с.].

Однако, не все так просто. Глава РАН заявил, что качество подготовки выпускников российских вузов продолжает падать: «Качество студента на выходе из университетов, скажем так, не улучшается, падает... Но тем не менее задача заключается в том, как нам качество студента повысить. Но когда университетам высказывается такая претензия, <...> то университеты кивают на школы: «А из школы кто приходит?» Такие что, извините, надо таблицу умножения учить»,- сказал А.М.Сергеев [8]. Проблема усугубляется еще и тем, что, выпускаемые вузами специалисты, должны ориентироваться в базах данных, но для этого необходимо освоить азы несколько специальностей(компьютерщик, программист, аналитик и т.д.) кроме основной, знать два-три иностранных языка, вот и приходится выпускникам самим доучиваться, чтобы быть в тренде. Эту проблему подтверждает и ректор Сколтеха Александр Кулешов: «вся фундаментальная наука абсолютно всеобща и интернациональна, и знания, полученные в одном месте, сразу тиражируются и распространяются по всему миру. Никто не живет на отдельной планете, у всех у нас планета одна. между желаемым и существующим можно только в содружестве образования, фундаментальных и общественных наук» [9]. Для решения поставленных временем задач, нужна система «проводников», имеющая обратную связь с исследователями, что предполагает сферическую композицию принятия решений (по произвольному количеству наук), смысл которой - в точках совпадения государственных интересов.

Как тут не вспомнить Г. Саймона американского ученого, который (в свое время) также озаботился подобными проблемами и образно их выразил: процесс принятия решений представляет собой «колесо в колесе», когда каждая стадия включает все остальные сочетания фаз и стадий, которые в процессе разработки проблемы могут принимать любые формы [10]. Это означает, что необходимо оценивать информацию по различным критериям, например: значимость, новизна, наукоемкость и дальнейшее ее сжатие до «информационной среды», которая по высказыванию академика В.А.Виноградова, «должна все более приближаться к знанию и опыту по степени ее охвата» [11], а на выходе синтез качественно различных знаний для определения критериев институциональных и инновационных процессов, без которых невозможно точно сформулировать цель, определяемую как «Разработка эффективных вариантов развития страны с учетом ее специфики и закономерностей мирового развития».

Необходимо совместить потенциалы исследователей, остановить процесс «растеканиеразбазаривание-утечка мозгов» на фоне потери восприимчивости к знанию некоторых возрастных категорий. Лишать оригинальности мышления тех, кто способен заявить о себе - недаль- 
новидно, критерии у каждого свои, а система информационного обеспечения - одна, и насколько она мобильна - настолько эти критерии становятся значимыми.

Необходима также активизация социальных сил, объективно заинтересованных в становлении подобных изменений. Главным критерием для принятия решений следует признать создание такой модели, которая стала бы, по меткому выражению Т.И. Заславской, «моделью системы управления экономикой, которую бы оставалось только взять и перенести из научных разработок в практику» [12 - с.32]. Главным тормозом в деле принятия решений следует признать монополизм, ему можно противопоставить свободу действий по критериям - творческая оригинальность, широта, быстрота реакции на общественный настрой. Монополизм, как известно, не предполагает конкуренцию, без которой все устремления думающих людей останутся на бумаге.

Развитие современной идеологии наукоемкого образования средствами книгопечатания и информационных технологий для интеграции накопленного потенциала научного знания, позволяет доказательно проследить преемственность в создании значимых Институтов власти, которые на Руси складывались столетиями, взять оттуда все лучшее для представления политической и ученой общественности, ибо, как писал тот же Д.Юм: «Установленная система правления имеет бесконечное преимущество именно из-за того обстоятельства, что она уже установлена, ибо основная масса человечества управляется авторитетом, а не разумом и никогда не придает веса тому, что не имеет рекомендации прошлого. Поэтому вмешательство в это дело или проведение экспериментов на основе всего лишь доверия к каким-либо предположительным соображениям или к философии, никогда не будет признаком мудрости правителя, который с почтением относится к тому, что несет на себе следы прошлого» [13].

Основополагающие критерии оценки инноваций в масштабах страны давно известны: «...общая направленность научно-технического развития, характеристика потенциала создания и освоения нововведений, институциональные и структурные параметры экономики, общенациональный инновационный климат» [14]. Что называется, была бы цель, а критерии найдутся, думается, важнее обозначить факторы сближения науки и реальной жизни, здесь уместно напомнить, что науке присущи три обязательных признака, известных еще со времен оных: познавательные методы, достоверность и общезначимость. С первыми двумя как будто ясно, а вот общезначимость имеет основополагающий признак - единодушие, ибо, как выразился Карл Ясперс: «Там, где на протяжении длительного времени не достигнуто единодушие всех мыслящих людей, возникает сомнение в общезначимости научного знания» [15 - с.101].

\section{Библиографический список}

1. Юм Д. Эссе.- М. Канон, 1996.- С.153.

2. Руссо Ж. Ж. Об общественном договоре. Трактаты. М., Канон-пресс, Кучково поле. М., 1998. - С.416.

3. Никифоров Л.В.Тенденции общественного развития и трансформации российского общества.- М.: ИЭ РАH. - 2004.- С.73.

4. Маркс, К. К критике гегелевской философии права. Введение.- Маркс, К. Энгельс, Ф. Сочинения. В 50 томах.-Издание второе. Т. 1.- М.: Государственное издательство политической литературы, 1955.- С. 422.

5. Никифоров Л.В.Тенденции общественного развития и трансформации российского общества.- М.: ИЭ РАН. - 2004.- С.16.

6. Г. Малинецкий. Выступление. https://zen.yandex.ru/media/id/5e274bc843863f00acd7ed97/antishvab-i-postkapi talizm-6083e0d7c17d7f239ef90a94

7. Бандурин В. В., Рацич Б. Г., Чатич М. Глобализация мировой экономики и Россия.- М.: Буквица, 1999.- С.79.

8. Сергеев А.М. Выступление. https://tass.ru/obschestvo/11383463?utm_source=yxnews \&utm_medium=desktop 16 МАЯ, 11:31

9. Кулешов А. Интервью.https://www.forbes.ru/forbeslife/429685-raz-net-konkurencii-i-umnye-lyudi-ne-nuzhnyrektor-skolteha-ob-investiciyah-v?utm_referrer=https\%3A\%2F\%19.05.2021 07:00

10. Саймон Г. Американский капитализм и управленческие решения (теория и методы принятия решений) / Под. ред. Л. И.Евенко. М.; Наука, 1977.

11. Проблемы информационной деятельности в области социального гуманитарного знания: Статьи и доклады. 30 лет в ИНИОН РАН (1972-2001 гг.)/РАН.ИНИОН.-М., 2001. 
12. Заславская Т. И. Социетальная трансформация российского общества. Деятельностно-структурная концепция. М.: Дело, 2002.- С.32

13. Давид Юм. Эссе, М.,, Канон 1996.-С.153

14. Экономические чудеса: уроки для России.- Колл. Авт. /Под общей редакцией Д.В.Кузина.- М., ОЛМА-ПРЕСС, 1994.

15. К.Ясперс. Характеристика современной науки, в кн.Смысл и назначение истории. М., Политизд. 1991. С. 101 